\title{
Need Analysis on English for Hotel at the Faculty of Tourism and Hospitality at Universitas Negeri Padang
}

\author{
Ratmanida $^{1}$, Sitti Fatimah ${ }^{2}$, Muhd. Al-Hafizh ${ }^{3}$, and Ira Meirina Chair ${ }^{4}$
}

\author{
${ }^{1}$ Universitas Negeri Padang, Padang and Indonesia, $\triangle$ (email), ratmanida@fbs.unp.ac.id \\ ${ }^{2}$ Universitas Negeri Padang, Padang and Indonesia, $ه$ (email), sitti.fatimah@fbs.unp.ac.id \\ ${ }^{3}$ English- Universitas Negeri padang, Padang and Indonesia, $\triangle$ (email), $m$ alhafizh@yahoo.com \\ ${ }^{4}$ Home Economics- Universitas Negeri Padang, Padang and Indonesia, $\triangle($ email), irameirinachair@fpp.unp.ac.id
}

\begin{abstract}
The importance of English proficiency in tourism sector, especially for hotel staff is undeniable. This study aims to explore the needs of English for tourism sector, in particular English needs for hotels. The result of the analysis of the needs will become the factors to be considered in developing English teaching materials for English subject at Faculty of Tourism and Hospitality. The sample of the study was selected using purposive random sampling technique, involving 41 staff. The data of the study were collected through questionnaire. The results of the study show that Listening skill is mostly needed. The second most needed skill is Speaking skill; while the third needed skill are Reading and Writing skills. The results of the study also reveal the topics, functions needed for each skill.
\end{abstract}

Keywords: English for tourism, need analysis, hotels, English Skills, Listening, Speaking

\section{INTRODUCTION}

English plays an important role in this globalisation era. Almost all sectors in life need English. It is a language that is mostly needed in countries all over the world. English has been used in almost 112 countries in the world, including in ASEAN countries. In 2015 president Joko Widodo issued Presidential Regulation number 69 of 2015 on Exemptions of Visit Visa (Visit Visa Regulation). The Visit Visa Regulation is an attempt of the Indonesian government to boost the tourist industry and increase the number of foreign tourist in Indonesia. In line with this Indonesian people should take an advantage of this visit., particularly to tourism and hotel sector. As part of the effort to take these opportunities in this competitive era, Indonesian people have to prepare the human resources that are competent in their field, One of the skills needed is English proficiency. Not only the professional who are responsible for this global competitiveness, but it is also applied to all people in Indonesia, including academic staff or lecturers at universities. Therefore, lecturers or staff at universities need to increase their awareness on this matter. This can be done by conducting a research on how to increase the English competence for both communication purposes as well as for ESP (English for specific purposes).

Padang State University as a Teacher Training Center which play a role to produce educational and professional resources contributes on the development of this country, particularly, in this competitiveness era. The efforts can be seen through research activities as part of the UNP road map, in order to lead UNP to become a research university. UNP has announced in the 2016-2020
UNP research master plan (revised edition) that the leading research theme was " The development of Science and Technology based on local potential through the quality of education and it's character ". One of West Sumatra's local potentials in tourism and hospitality is that there are 374 hotels, in which 58 hotels are categorized as the star hotel.

As a concrete manifestation of preparing educators and professionals in the fields of tourism and hospitality, UNP has opened a faculty called the Faculty of Tourism and Hospitality which was inaugurated on September 16, 2015. The Faculty of FPP has a mission to be an excellent Faculty in producing educators, professionals in the field of tourism and hospitality. They are also expected to have a strong leadership character, and be able to compete globally particularly at the ASEAN level. The students of the Tourism and Hospitality Faculty of UNP will be more involved with the work that are related to English. These jobs include, for example, hospitality, restaurants or other tourism sectors. Therefore, English for torurism, in particular, English for hotels, should be emphasized in order to improve students' English language competence.

Robinson [12] states that English For Specific Purposes (ESP) or English for special purposes is a form of approach in the teaching and use of English for specific fields and studies that are appropriate to the needs of the fields of science and professions of English users. The fields of science and profession that will be discussed in this study are for English for hospitality. Teaching English for special purposes has different approaches and assumptions from General English (GE.) ESP material refers to the needs of students (students' needs) and users 
of graduates themselves. The same thing was also said by Chan [3] who argued that teaching materials and syllabus and ESP objectives should be designed and developed based on the needs of students and graduates users because students both when they are in college and when they are going to work, the teaching materials must be relevant with their needs.

Based on the description above, it can be concluded that ESP is an approach in learning English that is different from general English. ESP refers to learning English which is oriented towards the special needs of learners according to the field of science and work. ESP material is based and developed based on needs analysis. Hoadley [6] stated that there are three main sources of information in conducting needs analysis, namely a) instructors, b) learners, and c) stakeholders).

Nekrasova [9] furthermore explained several ESP criteria including goal-oriented. This means that students who study English basiccally because of their needs, both for academic needs and for the occupational needs. Another feature is ESP based on need analysis (needs analysis) aims to find out as detail as possible the targets to be achieved in learning English. This shows that ESP is an approach to learning based on students' needs or stake holders' needs (target situation), in this case the need to be achieved is English for hospitality (English for hotels).

In order to set an effective English langage teaching and learning process at this faculty, there are many factors need to be considered. One of them is learning materials. Learning materials plays an important role in language learning, because it will promote learning activities, which later lead to the learning outcome. Learning materials, in particular, text book provides the basis of the content of lesson; the balanced of the skills taught, and the kinds of language practice students take in [Garton and Graves, 2014, p.19\}. Therfore,

English material for the students of the Department of Tourism should be relevant with academic needs and profesional needs. However, not all English material used in teaching Engglish relevant with their needs and condition in lanuage class [Ur, 1996; Richard , 2001]

Therefore it is necessary to conduct an in-depth study of the appropriate teaching materials for English at hospitality that are relevant with the results of a need analysis of target situation. The goals of this study is then to conduct a need analysis on English for hospitality based on target situation, in particular to identify the need of English for hospitality at hotels in Padang. The results of the analysis can then be formulated as an English language learning materials for universities that are relevant with this needs.

\section{METHOD}

The study aims to investigate the need of English for hospitality from hotel staff in Padang. It was conducted using descriptive design. It describes and analyzes the data as it is, as suggested by Gay [5]. The study population are all the star hotel staff in Padang. There are 26 hotels in Padang, classified as Star hotels (Badan Pusat Statistik
Kota Padang , 2019 ). For descriptive research, Gay [5] suggests that the sample are taken through purposive random sampling, the number of samples can be taken around $10 \%$ of the population, Gay [5] . Thus the samples for this study are hotel staff of three hotels in Padang, 9 (nine) are from Pangeran Hotel, 21 (twenty one) are from Basko Hotel, and and 11 (eleven) are from Bumi Minang Hotel. Therefore, the total number of sample for this study are 41 hotel staff. They were selected based on the following criteria: (1) Have a minimum one year working experience. Thus, they already know a lot of English language needs in hospitality. (2) Has an educational background, extensive experience about hospitality.

The data of this study was drawn from questionnaire. It aims to gain Information from the hotel staff in Padang about the need of English for hospitality, especially on the English language skills needed, the topics, the functions of communication in English, etc, The questionnaires applied four rating scale, namely, very important, important, less important, and not important. Soon after the data of the questionnaire had been collected, it was then classified based on the English language skill; listening, Speaking, Reading and Writing. The following category is topics, and function of English communication. This data was then tabulated and analyzed using percentage that based on Sudjana [14] as follows:

$$
\begin{aligned}
& \mathrm{P}=\mathrm{F} \times 100 \% \mathrm{~N} \\
& \mathrm{P}=\text { the percentage of response } \\
& \mathrm{F}=\text { Frequency } \\
& \mathrm{N}=\text { total number of responden }
\end{aligned}
$$

Percentage formula was used to find out percentage of respondents' responses, under four categories namely, "the highest need", "high need", "low need", and "the lowest need". The 4 (four) categories of Hotel Staff's response was then divided into two specific categories, namely "the high needed category" and "the less needed category". This separation was done due to the nature of data obtained in the field, in which the researcher was only concerned with need of English for hospitality of three star hotels in Padang. Therefore, the category is formulated and elaborated based on the aspect of the (high) needed category only, since the focus of this research is on the need analysis of English for Hospitality. The average amount of the calculation of the three hotels or mean became the finding of each category. The mean range then determines the level of the need, as shown in the following table.

Table 1. The mean range then determines the level of the need

\begin{tabular}{lll}
\hline Scale & Mean range & Need Level \\
\hline $\mathbf{4}$ & $75-100$ & The highest need \\
\hline $\mathbf{3}$ & $45-74.9$ & High need \\
\hline $\mathbf{2}$ & $25-44.9$ & Low need \\
\hline $\mathbf{1}$ & $10-24.9$ & The lowest need \\
\hline
\end{tabular}




\section{FINDING AND DISCUSSION}

The findings are organized to address the need of English for hospitality of Hotel staff in Padang. It describes the distribution of need analysis of English language skills, followed by the distribution of need analysis of each skill, accompanied by the data of each skill.

\section{The need of The English Language Skills}

In general, it is found that the need of English language skills, Listening, Speaking, Reading and Writing were evidenced in this study. However, the level of need of each skill is slightly different. Listening, Reading, and Writing have the similar need level; they were categorized as highly needed; Whereas, writing skill is categorized as Low need. The percentage of each skill that based on questionnaire analysis are shown table 2 .

Table 2. The need of English Language Skills

\begin{tabular}{|c|c|c|c|c|c|}
\hline \multirow[t]{2}{*}{ No } & \multirow{2}{*}{$\begin{array}{l}\text { English Language } \\
\text { Skills }\end{array}$} & \multicolumn{3}{|c|}{ the (high) needed category } & \multirow[t]{2}{*}{ Mean } \\
\hline & & $\begin{array}{c}\text { Kryiad Bumi Minang } \\
\text { Hotel }\end{array}$ & Pangeran Hotel & Basko Hotel & \\
\hline 1. & Listening & $10(100 \%)$ & $5(55.6 \%)$ & $12(57,1 \%)$ & $70,9 \%$ \\
\hline 2. & Speaking & $9(90 \%)$ & $5(55.6 \%)$ & $10(47,6 \%)$ & $64,4 \%$ \\
\hline 3. & Reading & $6(60 \%)$ & $5(55.6 \%)$ & $16(76,0 \%)$ & $63,8 \%$ \\
\hline 4. & Writing & $6(60 \%)$ & $3(33,3 \%)$ & $8(38,0 \%)$ & $43,7 \%$ \\
\hline
\end{tabular}

The chart shows that the "Listening Skill" was considered to be the highly needed English language skill for hospitality in Padang. The average percentage of Listening skills was $70,9 \%$. The second high needed English language skill is "Speaking Skill". The average percentage of Speaking skills is $64,4 \%$. The third highly needed English language skill is "Reading Skill". The average percentage of Reading skills is $64,4 \%$; While the average percentage of "Writing skills" is only 43,7\%. This skill is considered to be the low language skill needed for hospitality in Padang. It may be concluded that there are three English language skills needed for Hospitality in
Padang, namely, Listening, Speaking, and Reading, Whereas, the low needed skill is Writing.

\section{The Need of Listening Skill}

Listening is one of the skills needed in hospitality. It comprises the following topics, Asking and giving information, General topic (daily topics of communication), Food, drink, Complaint, Asking for service, Hotel reservation, Room Division, Giving and clarifying information, Asking and giving a help, Answering Questions and solving problem, Kitchen, Cooking method. The percentage of each topic that based on Questionnaire analysis are shown in table below

Table 3. Topics of Listening Skill

\begin{tabular}{|l|l|l|l|l|l|}
\hline \multirow{2}{*}{ No } & Topics of Listening & \multicolumn{3}{|c|}{ Mean } \\
\cline { 3 - 5 } & & \multicolumn{2}{|c|}{$\begin{array}{l}\text { Kryiad Bumi } \\
\text { Minang Hotel }\end{array}$} & Pangeran Hotel & Basko Hotel \\
& & $10(100 \%)$ & $6(75 \%)$ & $6(28,6 \%)$ & $67,8 \%$ \\
\hline 1 & Asking and giving information & $9(90 \%)$ & $(62.5 \%)$ & $6(28,6 \%)$ & $60,3 \%$ \\
\hline 2 & $\begin{array}{l}\text { General topic; daily topics of } \\
\text { communication }\end{array}$ & $9(90 \%)$ & $4(57,1 \%)$ & $5(23.8 \%)$ & $56,9 \%$ \\
\hline 3 & Food & $9(99,9 \%)$ & $4(50 \%)$ & $3(14,3 \%)$ & $54,7 \%$ \\
\hline 4 & Complaint & $9(90 \%)$ & $4(50 \%)$ & $5(23.8 \%)$ & $54,6 \%$ \\
\hline 5 & Drink & $7(70 \%)$ & $5(62,5 \%)$ & $5(23.8 \%)$ & $52,1 \%$ \\
\hline 6 & Asking for service & $7(70 \%)$ & $4(50 \%)$ & $7(33.3 \%)$ & $51,1 \%$ \\
\hline 7 & Asking and giving direction & $7(77,7 \%)$ & $3(37,5 \%)$ & $8(37.8 \%)$ & $51 \%$ \\
\hline 8 & Hotel reservation & $7(77,7 \%)$ & $4(44,4 \%)$ & $3(14,3 \%)$ & $45,4 \%$ \\
\hline 9 & Room Division & $6(66,6 \%)$ & $4(50 \%)$ & $4(19 \%)$ & $45,2 \%$ \\
\hline 10 & Giving and clarifying information & $7(70 \%)$ & $(37,5 \%)$ & $5(23.8 \%)$ & $43,7 \%$ \\
\hline 11 & Asking and giving a help & $6(60 \%)$ & $(50 \%)$ & $3(14.3 \%)$ & $41,4 \%$ \\
\hline 12 & $\begin{array}{l}\text { Answering Questions and solving } \\
\text { problem }\end{array}$ & & & & $28,3 \%$ \\
\hline 13 & Kitchen & $3(33,3 \%)$ & $3(37,5 \%)$ & $3(14,3 \%)$ & $24,2 \%$ \\
\hline 14 & Business division & $3(33,3 \%)$ & $2(25 \%)$ & $3(14,3 \%)$ & $23,7 \%$ \\
\hline 15 & Cooking method & $3(33,3 \%)$ & $1(14,2 \%)$ & $5(23.8 \%)$ & \\
\hline
\end{tabular}


In general, the table above shows that the topics of

Almost all the above topics are needed by the participant. This can be seen from the description on the response of the participants of the of the topics needed, for example; Asking and giving information (67,8\%), General topic; daily topics of communication $(60,3 \%)$, Food (56,9\%), Complaint ( 54,7\%), Drink (54,6\%), Offering service $(52,1 \%)$, Asking and giving direction $(51,1 \%)$, Hotel reservation (51\%), Room Division 45,4\%, and Giving and clarifying information $(45,2 \%)$,
Listening Skills are highly needed by hotel staff in Padang.

\section{The Need of Speaking Skill}

Speaking is one of the skills needed in hospitality. It comprises the following functions, Asking and giving information, daily communication, Asking, responding, and describing food, taking about drink, Asking, responding, explaining about room division, Giving and clarifying information, Asking and giving a help, Answering Questions and solving problem , Giving confirmation/clarification, Asking and giving direction , Offering services. The percentage of each function that based on Questionnaire analysis are shown in table below

Table 4. Functions of Speaking Skill

\begin{tabular}{|c|l|l|l|l|l|}
\hline No & \multirow{2}{*}{ Functions of Speaking Skill } & \multicolumn{3}{|c|}{ The (high) need } & Mean \\
\cline { 3 - 6 } & & $\begin{array}{l}\text { Kryiad Bumi } \\
\text { Minang Hotel }\end{array}$ & Pangeran Hotel & Basko Hotel & \\
\hline 1. & $\begin{array}{l}\text { Answering questions and solving } \\
\text { problems }\end{array}$ & $7(70 \%)$ & $5(62,5 \%)$ & $2(9,4 \%)$ & $47,3 \%$ \\
\hline 2. & Giving confirmation /clarification & $6(60 \%)$ & $5(62,5 \%)$ & $2(9,4 \%)$ & $43,9 \%$ \\
\hline 3. & Asking and giving direction & $9(90 \%)$ & $2(22,2 \%)$ & $4(18,7 \%)$ & $43,6 \%$ \\
\hline 4. & Asking and giving information & $6(60 \%)$ & $4(50 \%)$ & $3(14,2 \%)$ & $41,4 \%$ \\
\hline 5. & Offering services & $66,6 \%)$ & $3(37,5 \%)$ & $4(18,7 \%)$ & $40,9 \%$ \\
\hline 6. & Taking about drink & $8(80 \%)$ & $2(25 \%)$ & $3(14,2 \%)$ & $39,7 \%$ \\
\hline 7. & daily conversation & $7(70 \%)$ & $2(25 \%)$ & $5(23,7 \%)$ & $39,5 \%$ \\
\hline 8. & Asking and giving a help & $7(70 \%)$ & $2(28,6 \%)$ & $3(14,2 \%)$ & $37,6 \%$ \\
\hline 9. & $\begin{array}{l}\text { Asking, responding, and describing } \\
\text { food }\end{array}$ & $6(60 \%)$ & $3(33,3 \%)$ & $2(9,7 \%)$ & $34,3 \%$ \\
\hline 10. & $\begin{array}{l}\text { Asking, responding , explaining } \\
\text { about room division }\end{array}$ & $6(60 \%)$ & $2(22,2 \%)$ & $3(14,2 \%)$ & $32,1 \%$ \\
\hline 11. & Interview & $2(20 \%)$ & $2(22,2 \%)$ & $2(9,4 \%)$ & $17,2 \%$ \\
\hline 12. & business & $1(11,1 \%)$ & 0 & $3(14,2 \%)$ & $8,4 \%$ \\
\hline
\end{tabular}

In general, the table above shows that the functions of Speaking Skills are not fully needed by hotel staff in Padang. Almost all the above functions are not totally needed by the participants. This can be seen from the description on the response of the participants of the of the function needed, for example; Asking and giving information (41,4\%), daily communication (39,5\%), Asking , responding , and describing food (34,3\%), talking about drink 39,7\%), Asking , responding , explaining about room division $(32,1 \%)$, Giving and clarifying information (43,9\%), Asking and giving a help (37,6\%), Giving confirmation /clarification (43,9\%), Asking and giving direction $(43,6 \%)$, and Offering services $(40,9 \%)$ are all classified as low need, while Answering Questions and solving problem $(47,3 \%)$ is considered as high need.

\section{The Need on Mode of Communication}

The other aspect of Speaking skills needed in hospitality is Mode of communication. It comprises of the following ways of communication; Face to face , Communication in phone call, Communication on video call, Presentation with power point The percentage of each function that based on Questionnaire analysis are shown in table below.
Table 5. Mode of Communication

\begin{tabular}{|c|l|c|c|c|c|}
\hline No & $\begin{array}{l}\text { Mode of } \\
\text { Commu- } \\
\text { nication }\end{array}$ & $\begin{array}{l}\text { Kryiad } \\
\text { Bumi } \\
\text { Minang } \\
\text { Hotel }\end{array}$ & $\begin{array}{l}\text { Pange- } \\
\text { ran Hotel }\end{array}$ & $\begin{array}{c}\text { Bas- } \\
\text { ko } \\
\text { Hot } \\
\text { el }\end{array}$ & Mean \\
\hline 1. & $\begin{array}{l}\text { Face to } \\
\text { face } \\
\text { communic } \\
\text { ation }\end{array}$ & $8(88,8 \%)$ & $7(87,5 \%)$ & 0 & $58,7 \%$ \\
\hline 2. & $\begin{array}{l}\text { Communi } \\
\text { cation in } \\
\text { phone call }\end{array}$ & $9(90 \%)$ & $5(62,5 \%)$ & 0 & $50,8 \%$ \\
\hline 3. & $\begin{array}{l}\text { Communi } \\
\text { cation on } \\
\text { video call }\end{array}$ & 0 & $3(37,5 \%)$ & 0 & $12,5 \%$ \\
\hline 4. & $\begin{array}{l}\text { Presentati } \\
\text { on with } \\
\text { power } \\
\text { point }\end{array}$ & 0 & $1(12,5 \%)$ & 0 & $4,1 \%$ \\
\hline
\end{tabular}

The table above shows that the Mode of Communication of Speaking Skills like, face to face communication, and Communication in phone call are 
highly needed by hotel staff in Padang. This can be seen from the description on the response of the participants on the mode of communication needed, for example; Face to face $(58,7 \%)$, Communication in phone call $(50,8 \%)$

\section{The Need of Reading Skill}

Reading is one of the skills needed in hospitality. It comprises the following topics, Check in/out, Food, Hotel reservation, Hotel facilities and services, Hospitality industry, Drink, Job, A hotel concierge, Event planner, Housekeeper, Kitchen, Cooking method, and correspondent. The percentage of each topic that based on Questionnaire analysis are shown in table below.

Table 6. Topics of Reading Skill

\begin{tabular}{|c|l|c|c|c|c|}
\hline No & $\begin{array}{l}\text { Topics of } \\
\text { Reading } \\
\text { Skill }\end{array}$ & $\begin{array}{c}\text { Kryiad } \\
\text { Bumi } \\
\text { Minang } \\
\text { Hotel }\end{array}$ & $\begin{array}{c}\text { Pangera } \\
\text { n Hotel }\end{array}$ & $\begin{array}{c}\text { Basko } \\
\text { Hotel }\end{array}$ & $\begin{array}{c}\text { Mea } \\
\text { n }\end{array}$ \\
\hline 1 & $\begin{array}{l}\text { Check } \\
\text { in/out }\end{array}$ & $7(87,5 \%)$ & $8(100 \%)$ & $12(57,0 \%)$ & $81,5 \%$ \\
\hline 2 & Food & $7(87,5 \%)$ & $6(75 \%)$ & $17(80,9 \%)$ & $81,1 \%$ \\
\hline 3 & $\begin{array}{l}\text { Hotel } \\
\text { reservati } \\
\text { on }\end{array}$ & $8(88,8 \%)$ & $6(75 \%)$ & $15(71,4 \%)$ & $78,4 \%$ \\
\hline 4 & $\begin{array}{l}\text { Hotel } \\
\text { facilities } \\
\text { and } \\
\text { services }\end{array}$ & $8(72,7 \%)$ & $5(62,5 \%)$ & $18(85,5 \%)$ & $73,6 \%$ \\
\hline 5. & $\begin{array}{l}\text { Hospitali } \\
\text { ty } \\
\text { industry }\end{array}$ & $7(63,6 \%)$ & $4(57,1 \%)$ & $18(85,5 \%)$ & $68,7 \%$ \\
\hline 6 & Drink & $7(87,5 \%)$ & $3(37,5 \%)$ & $17(80,9 \%)$ & $68,6 \%$ \\
\hline 7 & Job & $8(88,8 \%)$ & $4(50 \%)$ & $14(66,6 \%)$ & $68,4 \%$ \\
\hline 8 & $\begin{array}{l}\text { A hotel } \\
\text { concierge }\end{array}$ & $6(66,6 \%)$ & $4(50 \%)$ & $16(75,8 \%)$ & $64,1 \%$ \\
\hline 9 & $\begin{array}{l}\text { Event } \\
\text { planner }\end{array}$ & $9(90 \%)$ & $3(37,5 \%)$ & $13(61,5)$ & $63 \%$ \\
\hline 10 & $\begin{array}{l}\text { Houseke } \\
\text { eper }\end{array}$ & $5(55,5 \%)$ & $4(50 \%)$ & $14(66,6 \%)$ & $57,3 \%$ \\
\hline 11 & Kitchen & $6(66,6 \%)$ & $2(28,6 \%)$ & $16(75,9 \%)$ & $57 \%$ \\
\hline 12 & $\begin{array}{l}\text { Cooking } \\
\text { method }\end{array}$ & $5(55,5 \%)$ & $2(25 \%)$ & $15(71,0 \%)$ & $50,5 \%$ \\
\hline 13 & $\begin{array}{l}\text { Correspo } \\
\text { ndent }\end{array}$ & $4(36,4 \%)$ & $2(22,2 \%)$ & $13(61,8 \%)$ & $40,1 \%$ \\
\hline & & & & & \\
\hline
\end{tabular}

In general, the table above shows that the topics of Reading Skills are Highly needed by hotel staff in Padang. Almost all the above topics are totally needed by the participants. This can be seen from the description on the response of the participants of the topics of Reading needed, for example Check in/out $(81,5 \%)$, Food $(81,1 \%)$, Hotel reservation $(78,4 \%)$, Hotel facilities and services (73,6\%), Hospitality industry $(68,7 \%)$, Drink $(68,6 \%)$, Job $(68,4 \%)$, A hotel concierge $(64,1 \%)$, Event planner $(63,0 \%)$, Housekeeper $(57,3 \%)$, Kitchen $(57 \%)$, Cooking method $(50,5 \%)$ are considered as high need, while the topic on Correspondent $(40,1 \%)$ is classified to be low need.

\section{The Need of Writing Skill}

Listening is one of the skills needed in hospitality. It comprises of the following topics, Asking and giving information, General topic (daily topics of communication), Food, drink, Complaint, Asking for service, Hotel reservation, Room Division, Giving and clarifying information, Asking and giving a help, Answering Questions and solving problem , Kitchen, Cooking method. The percentage of each topic that based on Questionnaire analysis are shown in table. Education needs $(51,4 \%)$, Business (44,2\%), Digital Correspondence (email, whatsApp, twitter,) $(38,9 \%)$, Private business $(22,6 \%)$

Table 6. Purpose of Writing Skill

\begin{tabular}{|l|l|l|c|c|c|}
\hline No & $\begin{array}{l}\text { Purpo- } \\
\text { se of } \\
\text { writing } \\
\text { Skill }\end{array}$ & $\begin{array}{l}\text { Kryiad } \\
\text { Bumi } \\
\text { Minang } \\
\text { Hotel }\end{array}$ & $\begin{array}{l}\text { Pangeran } \\
\text { Hotel }\end{array}$ & $\begin{array}{c}\text { Masko } \\
\text { Hotel }\end{array}$ & \\
\hline 1. & $\begin{array}{l}\text { Educatio } \\
\text { nal } \\
\text { needs }\end{array}$ & $6(66,6 \%)$ & $4(50 \%)$ & $8(37,7 \%)$ & $51,4 \%$ \\
\hline 2. & Business & $7(70 \%)$ & $2(25 \%)$ & $8(37,7 \%)$ & $44,2 \%$ \\
\hline 3. & $\begin{array}{l}\text { Digital } \\
\text { Correspo } \\
\text { ndence } \\
\text { (email, } \\
\text { whatsAp } \\
\text { p, } \\
\text { twitter, }\end{array}$ & $6(66,6 \%)$ & $1(12,5 \%)$ & $8(37,7 \%)$ & $38,9 \%$ \\
\hline 4. & $\begin{array}{l}\text { Private } \\
\text { busi-ness }\end{array}$ & $4(44,4 \%)$ & 0 & $5(23,5 \%)$ & $22,6 \%$ \\
\hline
\end{tabular}

The table above shows that the purposes of writing Skills are not Highly needed by hotel staff in Padang. Not all the above topics are needed by the participants. This can be seen from the description on the response of the participants of the purpose of writing, for example Education needs $(51,4 \%)$, Business $(44,2 \%)$, Digital Correspondence (email, whatsApp, twitter,) (38,9\%), Private business $(22,6 \%)$. It means that the purpose of writing for educational need is highly need, while the purpose for Business, Digital Correspondence (email, whatsApp, twitter,) $(38,9 \%)$, are considered to be low need.

Based on the description above, it can be concluded that all skills are needed by the hotel staff in Padang, however the need level of language skills is somewhat different. Reading skill, speaking skill and listening skill are considered to be highly needed while writing skill are considered to be low need. This finding is quite similar with the study conducted by Lestari and Isma, 2018 who conduct a study to find out the students' needs at Hotel Hospitality at SMKN 1 Bojonegoro, in which they found that all skills of language are generally important for hotel. The other findings that are related with the language skills are about the topics of Listening Skills, and reading, the functions of Speaking skills, and the purposes of writing skills. are found highly needed by hotel staff in Padang. Almost all the above topics are needed by the participant. 
In term of the topics of Listening Skills and the reading skills, the results of study show that they are highly needed by hotel staff in Padang. Almost all the above topics are needed by the participant, and event three topics of reading are considered to be mostly needed, such as the topics of Check in/out, Food, and Hotel reservation. The purpose of writng are considered low need. However, since we are in 4,0 era, the participant also think that they need the writing related with Digital Correspondence (email, whatsApp, twitter,) this probably due to the tendency of writing activity on digital form are increasing.

\section{CONCLUSIONS}

Needs analysis is part of the curriculum development. It is generally required before constructing English language teaching. The findings from this study therefore can provide an insight into the needs of language skills, topics, functions and purposes of English Skills used among hotel staffs who work in star hotel companies located in Padang. The result of the findings can be used as guidelines for developing English teaching materials for hotels, since the result of this study is expected to provide a baseline for obtaining a wider range of input into content, design and implementation of an English programme for hotel .

\section{REFERENCES}

[1] Basturkmen, H. (2012). Languages for Specific Purposes Curriculum Creation and Implementation in Australasia and Europe. The Modern Language Journal, 96, 59-70. Retrieved from http://www.jstor.org/stable/41478791

[2] Belcher, D. (2006). English for Specific Purposes: Teaching to Perceived Needs and Imagined Futures in Worlds of Work, Study, and Everyday Life. TESOL Quarterly, 40(1), 133-156. doi:10.2307/40264514

[3] Chan, Victoria. (2001). Determining Students' Language Needs in a Tertiary Setting. English Teaching Forum, Juli 2001.

[4] Donough, J.M. (1984) ESP in Perspective A Practical Guide. (London: Collin ELT, 1984), p.3.

[5] Gay. L.R. (1978). Educational Research: Competencies Analysis and Application. London. Merril Publishing Company.

[6] Hoadley- Maidment, (1980) dalam McDonough. ESP in Perspectives: A Practical Guide. (London: Collin Educational Publishing, 1984).p.38.

[7] Lam, J., Yeung, S., Leung, A., \& Lo, Y. (2012). Change in Curriculum Planning. In Curriculum Change and Innovation (pp. 125-148). Aberdeen, Hong Kong: Hong Kong University Press. Retrieved from http://www.jstor.org/stable/j.ctt1xwfn8.14

[8] Nunan, D (1991). Language Teaching Methodology, New York Prentice Hall.

[9] Nekrasova-Beker, T., \& Becker, A. (2017). Integrating Project-Based Learning into English for Specific-Purposes Classrooms: A Case Study of Engineering. In Long M. (Ed.), Language for Specific Purposes: Trends in Curriculum Development (pp. 101126). WASHINGTON, DC: Georgetown University Press. Retrieved from http://www.jstor.org/stable/j.ctt1ps3169.12

[10] Ratmanida. (2003). Analisis Kebutuhan Terhadap Bahasa Inggris Mahasiswa Jurusan Akuntansi di Perguruan Tinggi sekodya Padang. Laporan Penelitian (Unpublished), Universitas Negeri Padang.

[11] Rencana induk penelitian UNP tahun 2016-2020 (edisi revisi)

[12] Robinson,P. (1990) English For Specific Purposes (Oxford: Pergamon Press, Ltd, 1990), p.5.

[13] Senate Committee on Teaching and Learning. (2001). Teaching Evaluation Guide. In Newton J., Ginsburg J., Rehner J., Rogers P., Sbrizzi S., \& Spencer J. (Eds.), Voices from the Classroom: Reflections on Teaching and Learning in Higher Education (pp. 344-360). University of Toronto Press. Retrieved from http://www.jstor.org/stable/10.3138/j.ctt2tttj4.85

[14] Sudjana, N (2005). Penilaian hasil proses belajar mengajar / Nana Sudjana. Bandung: Remaja Rosdakarya

[15] Weyreter, M., \& Viebrock, B. (2014). Identity Construction in Adult Learners of English for Specific Purposes (ESP): Exploring a Complex Phenomenon. In AbendrothTimmer D. \& Hennig E. (Eds.), Plurilingualism and Multiliteracies: International Research on Identity Construction in Language Education (pp. 145-158). Frankfurt am Main: Peter Lang AG. Retrieved from http://www.jstor.org/stable/j.ctv2t4b81.11

[16] Lestari, Iin Widya, and Adi Isma. The need analysis of English material on Hotel Hospitality students at SMKN 1 Bojonegoro INacelt. Vol 2, No 1 (2018) 